\title{
Renal Acid-Base Transport: Old and New Players
}

\author{
Carsten A. Wagner Jana Kovacikova Paul A. Stehberger Christian Winter \\ Chahira Benabbas Nilufar Mohebbi \\ Institute of Physiology and Center for Integrative Human Physiology, University of Zurich, Zurich, Switzerland
}

\author{
Key Words \\ Acid-base transport, renal $\cdot$ Homeostasis $\cdot$ Renal \\ tubular acidosis
}

\begin{abstract}
Systemic acid-base homeostasis is the product of complex interactions between metabolism, regulated exhalation of $\mathrm{CO}_{2}$ by the lungs and acid or base excretion by the kidneys. The importance of renal acid-base transport has been highlighted by mutations identified in several proteins involved in this task in patients with inborn forms of renal tubular acidosis. The underlying mechanisms of disease have been further studied in genetically altered mouse models and cell culture. An interesting field of research has focused on the question how changes in metabolism or acid-base homeostasis are sensed and result in altered excretion of acid or bases by the kidney. Several hormonal pathways including aldosterone and endothelin were implicated, a novel subfamily of proton-sensing receptors has been identified, and signaling molecules described that are activated by changes in $\mathrm{pH}$.
\end{abstract}

Copyright (C) 2006 S. Karger AG, Basel

\section{Introduction}

The ability of the kidney to excrete acids or bases depends critically on the expression of various specialized and spatially arranged transport proteins and enzymes.
Their functional importance has been demonstrated by the identification of mutations in some of these proteins in patients with different forms of renal tubular acidosis (see below) and in mouse models deficient for the respective genes. The kidney employs three major processes in the maintenance of acid-base homeostasis: (i) the reabsorption of filtered bicarbonate mainly in the proximal tubule and to a lesser extent in the thick ascending limb; (ii) the excretion of acid/protons in the collecting duct, and (iii) the synthesis of ammonia and the use of ammonia, phosphate and citrate as so-called titratable acids to bind protons and thereby maximizing the kidneys ability to excrete protons.

\section{Bicarbonate Reabsorption and Handling of Titratable Acids in the Proximal Tubule}

The proximal tubule reabsorbs the bulk of filtered bicarbonate, approximately 70-80\% of the filtered load. This process requires a luminal carbonic anhydrase (CA type IV) facilitating the formation of $\mathrm{CO}_{2}$ and $\mathrm{H}_{2} \mathrm{O}$ from filtered $\mathrm{HCO}_{3}^{-}$and excreted $\mathrm{H}^{+}$. $\mathrm{CO}_{2}$ diffuses into the cell and is rapidly rehydrated and $\mathrm{HCO}_{3}^{-}$and $\mathrm{H}^{+}$formed catalyzed by a cytosolic $\mathrm{CA}$ (type II). $\mathrm{HCO}_{3}^{-}$is extruded into blood via the basolateral electrogenic $\mathrm{Na}^{+} / \mathrm{HCO}_{3}^{-}$cotransporter $\mathrm{NBCe1}$, whereas protons are secreted into urine via apical $\mathrm{Na}^{+} / \mathrm{H}^{+}$exchangers (isoforms NHE3 and possibly NHE8) and vacuolar type $\mathrm{H}^{+}$-ATPase [1]. Similar processes underlie reabsorption of bicarbonate in the

\section{KARGER \\ Fax +4161306 1234 E-Mail karger@karger.ch} www.karger.com
(C) 2006 S. Karger AG, Basel $1660-2137 / 06 / 1031-0001 \$ 23.50 / 0$

Accessible online at:

www.karger.com/nep
Carsten A. Wagner

Institute of Physiology, University of Zurich

Winterthurerstrasse 190

CH-8057 Zurich (Switzerland)

Tel. +41 44635 0659, Fax +41 44635 6814, E-Mail Wagnerca@access.unizh.ch 
Fig. 1. Transport mechanisms involved in acid-base transport and ammoniagenesis in the proximal tubule. For clarity processes are depicted in two different cells but occur in all cells of the proximal tubule. Bicarbonate absorption is mediated by apical $\mathrm{Na}^{+}$/ $\mathrm{H}^{+}$exchangers (NHE) and vacuolar $\mathrm{H}^{+}$ATPases in concert with extracellular and cytosolic carbonic anhydrases (CAII and CAIV). Bicarbonate is released into blood via the basolateral electrogenic $\mathrm{Na}^{+} / \mathrm{HCO}_{3}^{-}$ cotransporter (NBCe1). Ammoniagenesis takes place in the proximal tubule during normal conditions mainly in the S3 segment. It involves uptake of glutamine (Gln) from urine and blood via several apical and basolateral $\mathrm{Na}^{+}$-dependent amino acid transporters. Gln is converted to glutamate (Glu) by the action of the mitochondrial phosphate-dependent glutaminase (PDG) and further metabolized to $\alpha$-ketoglutarate $(\alpha-K G)$ via the glutamine dehydrogenase $(\mathrm{GDH})$. Eventually, glucose and $\mathrm{CO}_{2}$ are produced by the cytosolic phosphoenolpyruvate carboxykinase (PEPCK). During this process $\mathrm{HCO}_{3}^{-}$and $\mathrm{NH}_{3} / \mathrm{NH}_{4}^{+}$are formed. $\mathrm{NH}_{3}$ diffuses into the lumen whereas $\mathrm{NH}_{4}^{+}$ is transported via NHE into urine. During acidosis ammoniagenesis is increased and the expression of the basolateral glutamine transporter SNAT3 stimulated.

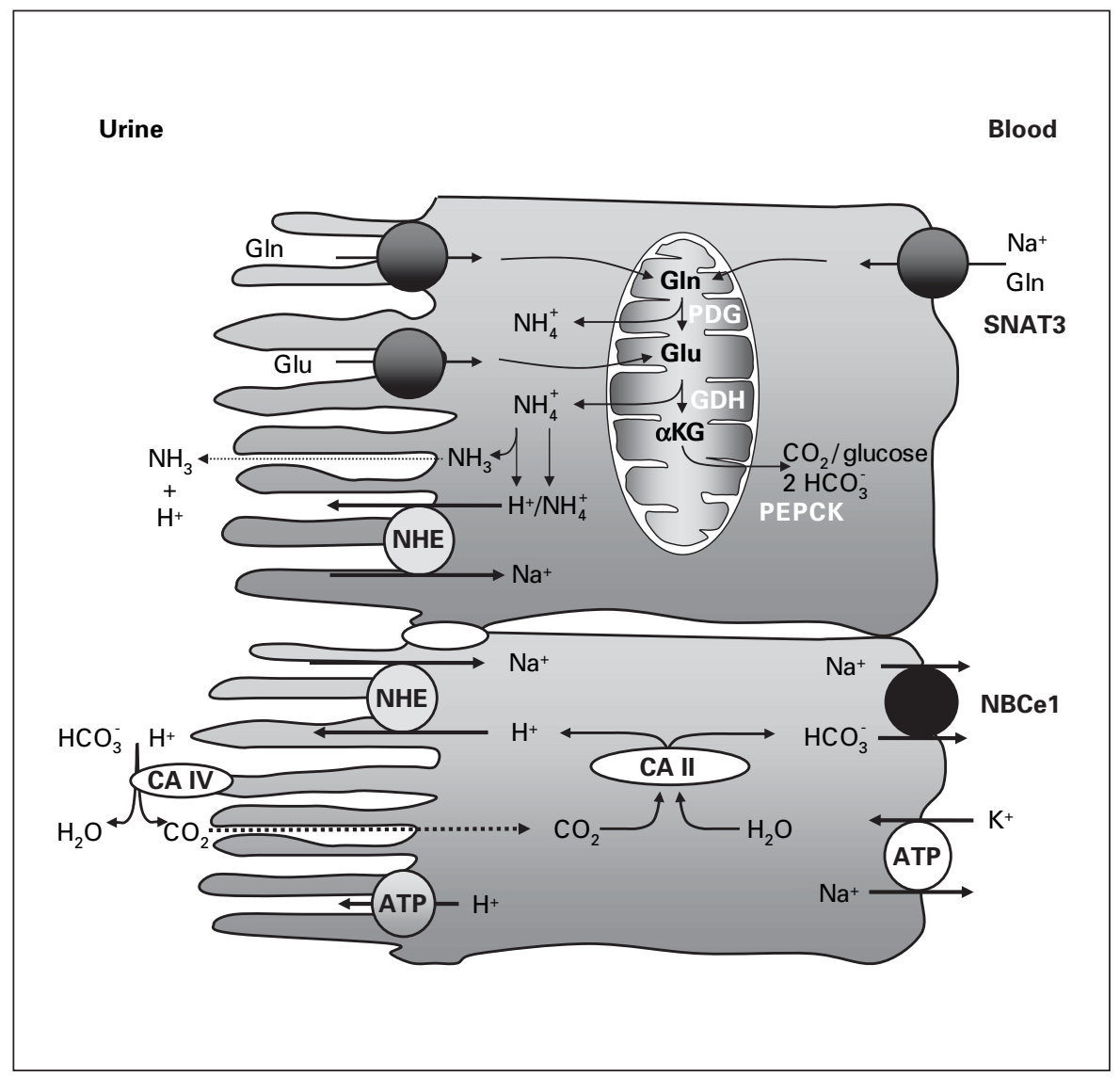

thick ascending limb accounting for about $20 \%$ of the filtered bicarbonate [2].

The proximal tubule also plays an important role in the synthesis of the major titratable acid, $\mathrm{NH}_{3} / \mathrm{NH}_{4}^{+}$, synthesized from glutamine yielding two $\mathrm{HCO}_{3}^{-}$and $\mathrm{NH}_{3}$ molecules as well as glucose. The synthesis of $\mathrm{NH}_{3} / \mathrm{H}_{4}^{+}$is highly regulated and stimulated during metabolic acidosis and requires the extraction of glutamine from blood across the basolateral membrane [3]. The amino acid transporter responsible for glutamine uptake into proximal tubular cells has been identified as SNAT3 (SLC38A3) and is upregulated both on mRNA and protein levels during metabolic acidosis [4, 5; Moret, Dave, Schulz, Verrey, Wagner, own unpublished observations]. Interestingly, SNAT3 is localized only in the late proximal tubule under normal conditions but its expression spreads to earlier proximal segments during acidosis. The second important titratable acid, phosphate, is also regulated by the proximal tubule as most phosphate is reabsorbed at this site via the apical $\mathrm{Na}^{+} /$phosphate cotransporter $\mathrm{NaPi}$-IIa. During acidosis renal phosphate excretion is increased.
In rats, but not in mice, acidosis downregulates NaPi-IIa activity and expression in the kidney [6, 7]. Interestingly, phosphate uptake from diet and expression of the intestinal NaPi-IIb phosphate transporter are stimulated during acidosis in mice [7]. This could provide phosphate for renal excretion and help to protect bone from massive phosphate loss during acidosis.

\section{Secretion of Protons or Bicarbonate from Intercalated Cells}

The final tuning of urinary acidification occurs in the late distal tubule, the connecting segment, the cortical and medullary collecting duct mainly through the action of intercalated cells [8]. At least two types of intercalated cells have been described based on morphological and functional criteria: acid-secretory type-A intercalated cells (A-IC) and bicarbonate-excreting type-B intercalated cells (B-IC). A-IC express vacuolar $\mathrm{H}^{+}$-ATPases on the luminal membrane excreting protons into urine which 


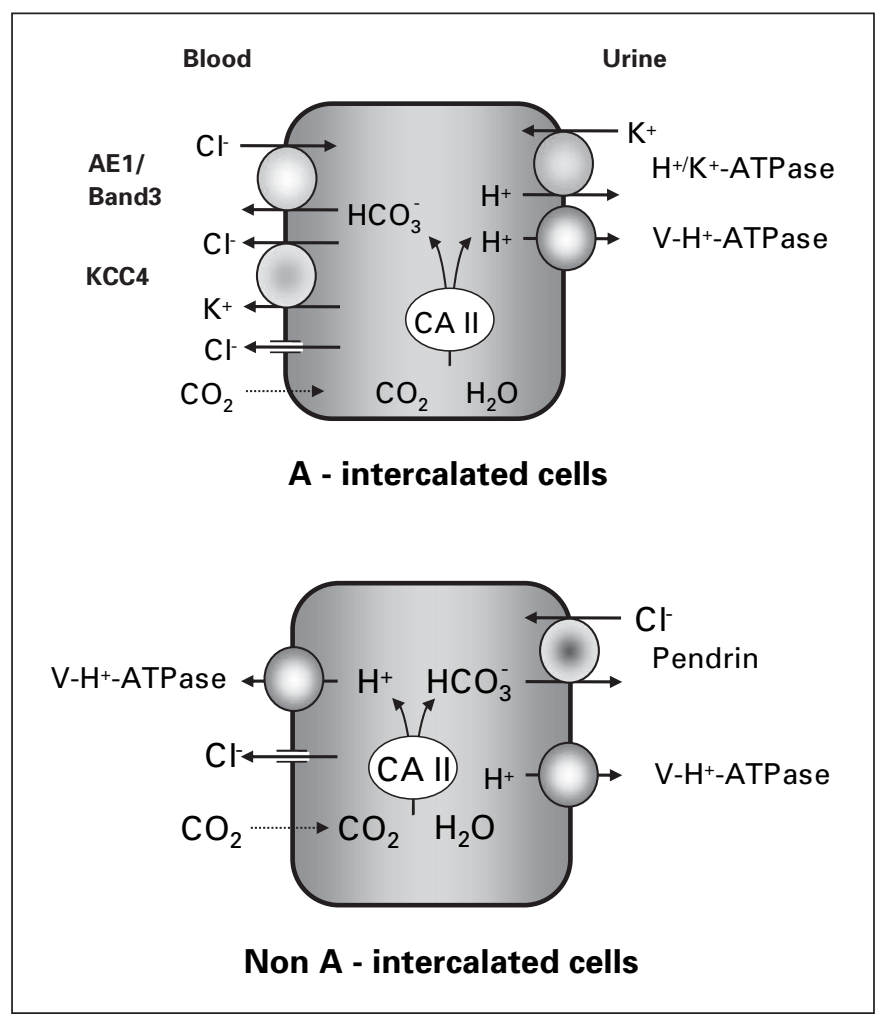

Fig. 2. Transport schemes for type A and non-type A intercalated cells. Type A intercalated express an apical $\mathrm{H}^{+}$-ATPase secreting protons into urine and a basolateral $\mathrm{Cl}^{-} / \mathrm{HCO}_{3}^{-}$exchanger, AE1, releasing bicarbonate into blood. Protons and bicarbonate are provided by a cytosolic carbonic anhydrase (CAII). Basolateral $\mathrm{Cl}^{-}$ channels and a $\mathrm{K}^{+} / \mathrm{Cl}^{-}$symporter (KCC4) may be involved in recycling chloride ions for AE1 activity. Non-type A intercalated cells express a vacuolar $\mathrm{H}^{+}$-ATPase on the basolateral side (type B IC) or on both sides (non-A/non-B IC). Both subtypes, however, express the $\mathrm{Cl}^{-} / \mathrm{HCO}_{3}^{-}$exchanger pendrin on their luminal side.

stem from the hydration of $\mathrm{CO}_{2}$ and subsequent formation of protons and bicarbonate by the cytosolic CAII isoform. The bicarbonate is released into blood via the basolaterally expressed chloride-bicarbonate exchanger AE1 (band 3). In contrast, B-IC express an apical chloride-bicarbonate exchanger excreting bicarbonate into urine. Protons are secreted into blood by basolateral $\mathrm{H}^{+}$ATPases. The apical $\mathrm{Cl}^{-} / \mathrm{HCO}_{3}^{-}$exchanger is most likely represented by pendrin. The function and regulation of pendrin has recently gained much attention because of its regulated expression in response to dietary chloride intake and the fact that pendrin-deficient mice are more sensitive to dietary salt restriction and do not increase blood pressure in response to aldosterone analogues [911]. These findings suggest a role of pendrin in chloride conservation by the kidneys and blood pressure regulation. Pendrin may also be important for protecting the body from the development of metabolic alkalosis as evident from pendrin-deficient mice and a mouse model lacking the B1 subunit of the basolateral proton pump of $\mathrm{B}-\mathrm{IC}$ and reduced pendrin abundance. Both mouse models are more prone to the development of metabolic alkalosis $[10,12]$. An additional $\mathrm{Cl}^{-} / \mathrm{HCO}_{3}^{-}$exchanger, AE4, has been identified in non-type A-IC. The subcellular localization of AE4 appears to be species specific. In the rabbit AE4 is localized in the apical membrane whereas in the rat and mouse AE4 is found on the basolateral side $[13,14]$.

\section{Regulation of Renal Acid-Base Transport}

The renal excretion of acid and base equivalents by the kidney is influenced by many factors such as diet, electrolyte status, physical activity, and drugs. Several hormones have been identified that could link metabolism and renal acid-base transport such as aldosterone, angiotensin II, endothelin, insulin-like growth factor 1, antidiuretic hormone, and thyroid hormones.

The vasoconstrictor endothelin has appeared over the last years as an important factor regulating renal acid secretion. Endothelin production in arteries and proximal tubules is increased during metabolic acidosis [15, 16]. The stimulatory effect of endothelin on $\mathrm{Na}^{+} / \mathrm{H}^{+}$ exchanger(s) and vacuolar $\mathrm{H}^{+}$-ATPases in the proximal and distal tubules is mostly mediated by ET-B receptors $[17,18]$. Furthermore, the increased urinary acid excretion in animals on a diet rich in protein depends on endothelin.

The importance of aldosterone for final urinary acidification has been known for decades and insufficiency of aldosterone synthesis, excretion or signaling underlies the hyperkalemic type of distal renal tubular acidosis (dRTA) [19]. Two findings have shed new light on aldosterone. First, a high-protein diet providing a dietary acid load stimulates renal acid excretion via endothelin, increasing aldosterone secretion [20]. Blocking either the endothelin or aldosterone pathway results in an inappropriate urinary acidification. Second, aldosterone stimulates vacuolar $\mathrm{H}^{+}$-ATPase activity also in a way distinct from the classic route (i.e. via the mineralocorticoid receptor and subsequent regulation of transcription). In freshly isolated mouse and human outer medullary collecting ducts, aldosterone directly stimulates insertion of proton pumps into the membrane in a rapid non-genomic manner. This 
effect is mediated by a complex signaling cascade via small $\mathrm{G}$ proteins, phospholipase $\mathrm{C}$, protein kinase $\mathrm{C}$, ERK1/2 kinases as well as elements of the protein kinase A-dependent pathway [21].

Besides these hormonal pathways, a novel concept of local $\mathrm{pH}$ sensing and regulation of acid-base transporters has emerged. Incubation of the renal OK cell line with an acid medium increases $\mathrm{Na}^{+} / \mathrm{H}^{+}$-exchange activity via a src-like tyrosine kinase and pyk2 [22, 23]. Pyk2 is activated in vitro in a slightly acidic buffer and phosphorylates and activates src [22]. However, it is unclear if pyk2 is the $\mathrm{pH}$ sensor itself. A novel subfamily of $\mathrm{G}$ proteincoupled receptors may contain such $\mathrm{pH}$ sensors. Three members of this subfamily, OGR1, GPR4 and TDAG8, are activated by extracellular protons with half-maximal activation occurring in the $\mathrm{pH}$ range of 7.4-7.0. Activation of OGR1 increases intracellular calcium and $\mathrm{IP}_{3}$ levels, known stimuli for $\mathrm{Na}^{+} / \mathrm{H}^{+}$-exchange activity [24]. GPR4 and TDAG8 couple to cAMP- and PKA-dependent pathways. Both OGR1 and GPR4 are expressed in the kidney and at least in the case of OGR 1 its localization in the basolateral membrane of almost all nephron segments appears ideally suited for an extracellular $\mathrm{pH}$ sensor [Mohebbi, Benabbas and Wagner, unpublished observations]. In addition to direct proton sensing, also sensors for $\mathrm{CO}_{2}$ and $\mathrm{HCO}_{3}^{-}$may exist. The recently discovered soluble adenylate cyclase is expressed in several $\mathrm{HCO}_{3}^{-}$-transporting epithelia including the kidney and is activated in the physiological $\mathrm{HCO}_{3}^{-}$concentration range [25]. In addition, evidence from isolated perfused proximal tubules suggest that basolateral $\mathrm{HCO}_{3}^{-}$or $\mathrm{CO}_{2}$ sensors exist and regulate fluid and bicarbonate fluxes [26].

\section{Inherited Disorders of Renal Acid-Base Transport}

Genes responsible for several rare inherited disorders of renal acid-base transport have been identified [27] Mutations in two genes, the $\mathrm{Na}^{+} / \mathrm{HCO}_{3}^{-}$-cotransporter NBCe1 (SLC4A4) and CAII, cause defective bicarbonate absorption in the proximal tubule. The gene encoding the electrogenic $\mathrm{Na}^{+} / \mathrm{HCO}_{3}^{-}$cotransporter (SLC4A4) underlies proximal renal tubular acidosis associated with blindness. Patients suffer from excessive urinary bicarbonate wasting and severe metabolic acidosis. The transporter is not only expressed on the basolateral side of the proximal tubule but also in the eye. Functional analysis of a number of mutants revealed that some mutants are retained in the endoplasmic reticulum, others are inserted into the membrane but show reduced function, and at least in the case of one mutant aberrant trafficking to the apical membrane in polarized cells was found [28, 29]. Mutations in the CAII gene cause a mixed type of proximal and dRTA due to its expression in both segments. Patients also suffer from cerebral calcification and osteopetrosis [30].

Inherited forms of dRTA can be caused by mutations either in two different subunits of the vacuolar $\mathrm{H}^{+}$-ATPase (ATP6V1B1 (B1 subunit), ATP6V0A4 (a4 subunit)) or the $\mathrm{Cl}^{-} / \mathrm{HCO}_{3}^{-}$-exchanger AE1 (Band 3, SLC4A1) [1, 27]. All forms are clinically characterized by hyperchloremic metabolic acidosis and hypokalemia and are often associated with retarded growth in infants with rickets. In adults, osteomalacia develops with high urinary calcium and nephrocalcinosis and nephrolithiasis. dRTA due to mutations in proton pump subunits is transmitted in an autosomal recessive way, whereas dRTA caused by AE1 mutations mostly follows an autosomal dominant inheritance. In rare cases, AE1 mutations can also cause autosomal recessive dRTA which has been detected in several patients in Southeast Asia [27].

Patients with mutations in the B1 proton pump subunit often also suffer from sensorineural deafness due to its expression in the inner ear. A mouse model deficient for the Atp6v1b1 gene has been generated and shown to develop an incomplete dRTA [31]. Due to the expression of the B1 subunit also in bicarbonate-secretory type B intercalated cells, mice lacking the B1 subunit are susceptible to more severe metabolic alkalosis [12]. Thus proton pumps containing the B1 subunit are involved in both acid secretion as well as in bicarbonate secretion during metabolic acidosis or alkalosis, respectively.

The AE1 chloride-bicarbonate exchanger is expressed both in red blood cells (RBC) and in acid-secretory type A-IC. Due to this expression pattern, mutations in the AE1 gene cause spherocytosis, Southeast Asian ovalocytosis and dRTA. However, with rare exceptions, only either RBC or the kidney are affected. This may be partially explained by two different observations. AE1 interacts in RBC with glycophorinA and this interaction functionally rescues many mutations observed in dRTA [32]. However, glycophorin A is not present in intercalated cells [32] and its absence may thus cause a renal defect, whereas the mutations have less functional consequences in RBC. Second, wild-type AE1 has to be sorted to the basolateral side of type-A intercalated cells in order to mediate the vectorial transport of bicarbonate into blood. Some dRTA mutations when expressed in polarized cell lines appear at the apical membrane or are retained intracellularly [33, 34]. Missorting would obvious- 
ly not affect AE1 function in non-polarized RBC but reverse the physiological direction of transport in kidney. However, it remains to be clarified if the mistargeting of mutant AE1 also occurs in vivo. dRTA caused by mutations in AE1 is mostly inherited in an autosomal dominant way in contrast to other genetic forms of dRTA. It has been suggested that the formation of functional heterodimers of normal and mutant AE1 may explain this pattern of inheritance. This interpretation is partly supported by two observations. A common mutant found in Southeast Asian ovalocytosis is functionally inactive and decreases transport activity in $\mathrm{RBC}$ without giving rise to dRTA [35]. Secondly, a mouse model lacking AE1 both in RBC and the kidney. Mice lacking one allele (heterozygotes) show no sign of metabolic acidosis whereas homozygotes completely lacking AE1 show a severe phenotype with high postnatal lethality, very low hematocrit and hemoglobin levels. Surviving mice suffer from dRTA, severe hyperchloremic metabolic acidosis, growth retardation, nephrocalcinosis with high urinary calcium and phosphate levels and low urinary citrate. In addition, mice are unable to concentrate urine and are dehydrated. However, the vasopressin-regulated AQP2 water channel is found predominantly in intracellular vesicles in the inner medulla pointing to a deranged regulation and possibly explaining the concentrating defect also seen in dRTA patients [36]. The defective AQP2 regulation may at least in part be explained by the concomitant hypercalciuria that may activate calcium-sensing receptors inhibiting AQP2 trafficking [37].

\section{Conclusion and Outlook}

Work over the last few years has identified a number of novel transport proteins that contribute directly or indirectly to the kidney's ability to excrete acid or bicarbonate, respectively. Rare mutations found in patients with several forms of renal tubular acidosis in some of these transport proteins have made it possible to gain deeper insight into mechanisms of renal acid-base transport. Newly developed genetic animal models facilitate the examination of transport processes and their regulation, and identify compensatory mechanisms activated by loss of function. However, little is known at present about the signals by which kidney cells sense systemic or local changes in acid-base balance. Hormones such as endothelin and the angiotensin-aldosterone system contribute to regulation. Novel putative proton-sensing receptors may also be involved in this task, however, their physiological role remains to be proven. The cellular events triggered by changes in acid-base homeostasis have only begun to be unraveled. Their elucidation will deepen our understanding of how cells in general and kidney cells in particular regulate intra- and extracellular $\mathrm{pH}$ homeostasis.

\section{Acknowledgements}

We thank J. Biber, J.P. Geibel, G. Giebisch, H. Murer, and F. Verrey for many discussions. Work in the authors' laboratory was supported by the Swiss National Research Foundation and the 6th EU frame work projects EUGINDAT and EuReGene (005085).

\section{References}

$\checkmark 1$ Wagner CA, Finberg KE, Breton S, Marshansky V, Brown D, Geibel JP: Renal vacuolar $\mathrm{H}^{+}$-ATPase. Physiol Rev 2004; 84:12631314.

2 Capasso G, Unwin R, Rizzo M, Pica A, Giebisch G: Bicarbonate transport along the loop of Henle: molecular mechanisms and regulation. J Nephrol Suppl 2002;5:S88-S96.

3 Nagami GT: Renal ammonia production and excretion; in Seldin D, Giebisch G (eds): The Kidney. Physiology and Pathophysiology, ed 3. Philadelphia, Lippincott Williams \& Wilkins, 2000, pp 1995-2013.

4 Karinch AM, Lin CM, Wolfgang CL, Pan M, Souba WW: Regulation of expression of the SN1 transporter during renal adaptation to chronic metabolic acidosis in rats. Am J Physiol Renal Physiol 2002;283:F1011-F1019.
5 Solbu TT, Boulland JL, Zahid W, Lyamouri Bredahl MK, Amiry-Moghaddam M, StormMathisen J, Roberg BA, Chaudhry FA: Induction and targeting of the glutamine transporter SN1 to the basolateral membranes of cortical kidney tubule cells during chronic metabolic acidosis suggest a role in $\mathrm{pH}$ regulation. $\mathrm{J}$ Am Soc Nephrol 2005;16:869-877.

6 Ambuhl PM, Zajicek H K, Wang H, Puttaparthi K Levi M: Regulation of renal phosphate transport by acute and chronic metabolic acidosis in the rat. Kidney Int 1998;53: 1288-1298.

7 Stauber A, Radanovic T, Stange G, Murer H, Wagner CA, Biber J: Regulation of intestinal phosphate transport II. Metabolic acidosis stimulates $\mathrm{Na}^{+}$-dependent phosphate absorption and expression of the $\mathrm{Na}^{+}-\mathrm{P}_{\mathrm{i}}$ cotransporter NaPi-IIb in small intestine. Am J Physiol Gastrointest Liver Physiol 2005;288:G501G506.
8 Wagner CA, Geibel J P: Acid-base transport in the collecting duct. J Nephrol Suppl 2002;5: S112-S127.

-9 Quentin F, Chambrey R, Trinh-Trang-Tan MM, Fysekidis M, Cambillau M, Paillard M, Aronson PS, Eladari D: The $\mathrm{Cl}^{-} / \mathrm{HCO}_{3}^{-}$exchanger pendrin in the rat kidney is regulated in response to chronic alterations in chloride balance. Am J Physiol Renal Physiol 2004;287: F1179-F1188.

10 Verlander JW, Hassell KA, Royaux IE, Glapion DM, Wang ME, Everett LA, Green ED, Wall SM: Deoxycorticosterone upregulates PDS (Slc26a4) in mouse kidney: role of pendrin in mineralocorticoid-induced hypertension. Hypertension 2003;42:356-362.

11 Wall SM, Kim YH, Stanley L, Glapion DM, Everett LA, Green ED, Verlander JW: $\mathrm{NaCl}$ restriction upregulates renal Slc26a4 through subcellular redistribution: role in $\mathrm{Cl}^{-}$conservation. Hypertension 2004;44:982-987. 
-12 Kovacikova J, Paunescu T, Bacic D, Finberg KE, Lifton RP, Breton S, Brown D, Wagner $\mathrm{CA}$ : B-intercalated cell function is deficient in mice lacking the $\mathrm{B} 1$ subunit of the $\mathrm{H}^{+}$-ATPase (abstract). J Am Soc Nephrol 2004;15:FPO025.

13 Ko SBH, Xiang L, Hager H, Rojek A, Choi JY, Licht C, Suzuki M, Muallem S, Nielsen S, Ishibashi K: AE4 is a DIDS-Sensitive $\mathrm{Cl}^{-} / \mathrm{HCO}_{3}^{-}$ exchanger in the basolateral membrane of the rat and mouse renal CCD and the SMG duct. Am J Physiol Cell Physiol 2002;283:C1206C1218.

$\checkmark 14$ Tsuganezawa H, Kobayashi K, Iyori M, Araki T, Koizumi A, Watanabe S, Kaneko A, Fukao T, Monkawa T, Yoshida T, Kim DK, Kanai Y, Endou H, Hayashi M, Saruta T: A new member of the $\mathrm{HCO}_{3}^{-}$transporter superfamily is an apical anion exchanger of beta-intercalated cells in the kidney. J Biol Chem 2001;276: 8180-8189.

15 Licht C, Laghmani K, Yanagisawa M, Preisig PA, Alpern RJ: An autocrine role for endothelin-1 in the regulation of proximal tubule NHE3. Kidney Int 2004;65:1320-1326.

-16 Wesson DE, Simoni J, Green DF: Reduced extracellular $\mathrm{pH}$ increases endothelin-1 secretion by human renal microvascular endothelial cells. J Clin Invest 1998;101:578-583.

17 Laghmani K, Preisig PA, Moe OW, Yanagisawa M, Alpern RJ: Endothelin-1/endothelin$B$ receptor-mediated increases in NHE3 activity in chronic metabolic acidosis. J Clin Invest 2001;107:1563-1569.

18 Wesson DE, Dolson GM: Endothelin-1 increases rat distal tubule acidification in vivo. Am J Physiol 1997;273:F586-F594.

19 DuBose TD Jr, Alpern RJ: Renal tubular acidosis; in Scriver CR, Beaudet AL, Sly WS, Valle D (eds): The Metabolic and Molecular Bases of Inherited Disease, ed 8. New York, McGraw-Hill, 2001, pp 4983-5021.

20 Khanna A, Simoni J, Wesson DE: Endothelininduced increased aldosterone activity mediates augmented distal nephron acidification as a result of dietary protein. J Am Soc Nephrol, 2005;16:1929-1935.
-21 Winter C, Schulz N, Giebisch G, Geibel JP, Wagner CA: Nongenomic stimulation of vacuolar $\mathrm{H}^{+}$-ATPases in intercalated renal tubule cells by aldosterone. Proc Nat Acad Sci USA 2004;101:2636-2641.

22 Li S, Sato S, Yang X, Preisig PA, Alpern RJ: Pyk2 activation is integral to acid stimulation of sodium/hydrogen exchanger 3 . J Clin Invest 2004;114:1782-1789.

23 Tsuganezawa H, Sato S, Yamaji Y, Preisig PA, Moe OW, Alpern RJ: Role of c-SRC and ERK in acid-induced activation of NHE3. Kidney Int 2002;62:41-50.

24 Ludwig MG, Vanek M, Guerini D, Gasser JA, Jones CE, Junker U, Hofstetter H, Wolf RM, Seuwen K: Proton-sensing G-protein-coupled receptors. Nature 2003;425:93-98.

25 Chen Y, Cann MJ, Litvin TN, Iourgenko V, Sinclair ML, Levin LR, Buck J: Soluble adenylyl cyclase as an evolutionarily conserved bicarbonate sensor. Science 2000;289:625-628.

26 Zhou Y, Zhao J, Bouyer P, Boron WF: Evidence from renal proximal tubules that $\mathrm{HCO}_{3}^{-}$ and solute reabsorption are acutely regulated not by $\mathrm{pH}$ but by basolateral $\mathrm{HCO}_{3}^{-}$and $\mathrm{CO}_{2}$. Proc Nat Acad Sci USA 2005; 102:38753880.

27 Alper SL: Genetic diseases of acid-base transporters. Annu Rev Physiol 2002;64:899-923.

28 Dinour D, Chang MH, Satoh J, Smith BL, Angle N, Knecht A, Serban I, Holtzman EJ, Romero MF: A novel missense mutation in the sodium bicarbonate cotransporter (NBCe1/ SLC4A4) causes proximal tubular acidosis and glaucoma through ion transport defects. J Biol Chem 2004;279:52238-52246.

-29 Li HC, Szigligeti P, Worrell RT, Matthews JB, Conforti L, Soleimani M: Missense mutations in $\mathrm{Na}^{+}: \mathrm{HCO}_{3}^{-}$cotransporter $\mathrm{NBCl}$ show abnormal trafficking in polarized kidney cells: a basis of proximal renal tubular acidosis. Am J Physiol Renal Physiol 2005;289:F61-F71.

30 Sly WS, Shah GN: The carbonic anhydrase II deficiency syndrome: osteopetrosis with renal tubular acidosis and cerebral calcification; in Scriver CR, Beaudet AL, Sly WS, Valle D (eds): The Metabolic and Molecular Bases of Inherited Disease. New York, McGraw-Hill, 2001, pp 5331-5343.
31 Finberg KE, Wagner CA, Bailey MA, Paunescu TG, Breton S, Brown D, Giebisch G, Geibel JP, Lifton RP: The B1-subunit of the $\mathrm{H}^{+}$ATPase is required for maximal urinary acidification. Proc Natl Acad Sci 2005;102:1361613621.

32 Tanphaichitr VS, Sumboonnanonda A, Ideguchi H, Shayakul C, Brugnara C, Takao M, Veerakul G, Alper SL: Novel AE1 mutations in recessive distal renal tubular acidosis. Lossof-function is rescued by glycophorin A. J Clin Invest 1998;102:2173-2179.

33 Devonald MA, Smith AN, Poon JP, Ihrke G, Karet FE: Non-polarized targeting of AE1 causes autosomal dominant distal renal tubular acidosis. Nat Genet 2003;33:125-127.

34 Toye AM, Banting G, Tanner MJ: Regions of human kidney anion exchanger 1 (kAE1) required for basolateral targeting of kAE1 in polarised kidney cells: mis-targeting explains dominant renal tubular acidosis (dRTA). J Cell Sci 2004; 117:1399-1410.

35 Bruce LJ, Wrong O, Toye AM, Young MT, Ogle G, Ismail Z, Sinha AK, McMaster P, Hwaihwanje I, Nash GB, Hart S, Lavu E, Palmer R, Othman A, Unwin RJ, Tanner MJ: Band 3 mutations, renal tubular acidosis and South-East Asian ovalocytosis in Malaysia and Papua New Guinea: loss of up to $95 \%$ band 3 transport in red cells. Biochem J 2000;350:4151.

36 Stehberger PA, Stuart-Tilley AK, Shmukler BE, Alper SL, Wagner CA: Impaired distal renal acidification in a mouse model for distal renal tubular acidosis lacking the AE1 (Band 3) $\mathrm{Cl}^{-} / \mathrm{HCO}_{3}^{-}$exchanger (Slc4a1) (abstract). J Am Soc Nephrol 2004; 15:F-PO008.

37 Sands JM, Naruse M, Baum M, Jo I, Hebert SC, Brown EM, Harris HW: Apical extracellular calcium/polyvalent cation-sensing receptor regulates vasopressin-elicited water permeability in rat kidney inner medullary collecting duct. J Clin Invest 1997;99:1399-1405. 